\title{
On the Creative Power of Music (Performing Secrets and the State of "Godly Sorrow" of Sergei Rachmaninoff)
}

\author{
Sadakatsu Tsuchida ${ }^{1, *}$
}

\author{
${ }^{1}$ Shokei-gakuin University, Sendai, Japan \\ *Corresponding author. Email: sadakatsu2002@shokei.ac.jp
}

\begin{abstract}
The article focuses on a topic that researchers usually neglect - the spiritual side of artistic performance : How to imagine, hear or produce the sound? Where from should a musician derive strength and energy for stage performance? Where is the source of creative inspiration? The author suggests analyzing these issues based on the published thoughts of Sergei Rachmaninoff.
\end{abstract}

Keywords: state of mind of a performer, musical performance, source of creative inspiration, energy, power

of music, Rachmaninoff

\section{INTRODUCTION}

Performing music is energy. It embraces beating, breathing, intonation and the power similar to wave and wind force; it is something invisible, animate, brought by the body and soul of the performer.

How to imagine, hear or produce the sound? Where from should a musician derive strength and energy for stage performance, which is always intense and requires the musician to be fully involved and efficient? Where is the source of creative inspiration? These questions are always a matter of concern to those performing music.

Technique, musicality and spirituality inextricably intertwine in technical mastery. By spirituality we mean the state of mind and cultural literacy in general, including the vision of the composition, the reason and purpose of playing, and the worldview. Spirituality is exactly what can make the performance of a musical piece outstanding. According to S.V. Rachmaninoff, the student "is to understand what provides the integrity, organicity, power and grace in the individual piece of music" [1,].

The present article, which focuses on the spiritual aspect of music and the necessary state of mind of the performer, attempts to find the answers to the questions above.

\section{TWO ASPECTS THAT DETERMINE THE QUALITY OF THE PERFORMANCE}

Let us consider the two aspects that determine the quality of the performance: the directions "from the earth" (exercise) and "from Heaven" (inspiration).

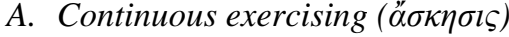

Yukiko Konishi, a music teacher teaching the author in his childhood, drew her students' attention to the importance of continuous exercising and often said, "No jewel will sparkle if is not polished."[2] There should be no interruptions to exercising for a musician; otherwise, their vital creative power will immediately begin to wane.

Exercise, "ő $\sigma \kappa \eta \sigma ı \varsigma "$ in Greek, is a word meaning both "exercise" and "religious deed".

Venerable Barsanuphius of Optina, one of the centres of the Russian Orthodox monasticism, who lived almost at the same time as S.V. Rachmaninoff, left a few words about art. The following statement of his is of particular interest for us: "Artists always have a streak of asceticism, and the more outstanding the artist, the brighter the flame of his religious mysticism is." [3]

This is the view towards the art, according to the Orthodox Church doctrine. The word "asceticism" used above specifically carries the meaning of the Greek

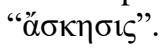

Saying "When performing creative work, always be in the privacy of your own mind," [4] Rachmaninoff convinces the reader of the need for some kind of 
creative asceticism. In his "Reminiscences" he writes the following: "A deep affinity for the land is inherent in every Russian, more than in any other nation. [...] The thoughts of Russian people about the land are characterized by striving for serenity, silence, taking delight in the nature around, and partly for inwardness and isolation. It seems to me that every Russian person is a hermit to a certain extent." [5]

Interestingly enough, not only does S.V. Rachmaninoff mention "striving for serenity and silence" as a trait of Russian people, but also for taking pleasure in "inwardness and isolation". In other words, saying that "every Russian person is a hermit to a certain extent", he recognizes the presence of the monastic spirit in Russian people ${ }^{1}$. He continues writing, "I highlight this craving for the land, as I myself have it, too." [6] Therefore, the described character traits are also inherent in the composer himself.

In his reminiscences about S.V. Rachmaninoff, Kōsaku Yamada, the famous Japanese composer remarked, "His [Rachmaninoff's] appearance and mild nature left a lasting impression on me, he resembled a high-ranking ecclesiastic"; "His facial expression was of a serious scientist, rather than of a musician"; "There was something oriental about his appearance"; "His image of the "Thinker", the solid rock." [7] Thus, Kōsaku Yamada perceived Rachmaninoff's spiritual essence as that of a "high-ranking ecclesiastic".

Nonetheless, is asceticism important? Why should a musician forbear? Apparently, it is often necessary for athletes, artists and religious people. In this article, however, we consider why musicians need forbearance.

\section{B. Synergism of inspiration}

Forbearance helps the performer to relieve stress and to gain considerable strength before the stage performance. It is necessary so that a musician can be fully stretched and can overreach themselves on stage. An essential part is the preparation by cleansing one's mind and body by fasting and prayer, as indicated in the Gospel of Matthew 17:21. The rules of spiritual life (fasting for the body, prayer for the soul) are directly applicable to creativity. As Japanese proverbs say, 「二 鬼を追う者、一鬼も得ず」(“He who chases two hares will catch neither”), and 「点滴穿石」 ("Constant dropping wears away a stone"). We would like to highlight the focus on auditory concentration during the performance, as the ability to "hear well" is likely to make the playing more vibrant.

As it is often said in Russia, "Angels are a light for monks, monks are a light for laymen".
In the mid-90s, self-playing pianos appeared in Japan. Koichiro Sato, Professor at Toho Gakuen, asked his students, "At last the time has come when Stanislav Bunin (a pianist from Russia, well-known in Japan) can play in every house. However, what is the difference between automatically played music and a live performance? Can a live performance, where minor hiccups are inevitable, surpass the ideal automatic play? If so, then how?" None of the students seemed to be able to answer. Prof. Sato's answer was as follows: "Automatic play is the extraction of pre-programmed sounds from the instrument, while in the case of a live performance a musician selects the appropriate sound at a particular moment of time by ear." Is not this the very truth itself?

Preforming is a unique moment of infinite being, the life of "ichigo ichie" (一期 一 会), the opportunity that is given only once, the first and the last simultaneously. Both the performer and the audience find themselves in the state of uncertainty, when no one knows what will happen in a moment. The recorded performance (the automatic play in particular) on the contrary can guarantee the fitting end of the play. It always has the same character and does not reflect the peculiarities of the place and time of the performance. Consequently, the audience ends up being in a different state than the performer. There is no unity; they neither live the moment together, nor feel the miracle of music being born. ${ }^{2}$

A performance when a musician themselves does not hear well enough the sounds being born, becomes lifeless, dry and harsh. This often results from the psychological pressure at the start of the performance and the performer left to their own devices. On the contrary, playing guided by music - when the musician's soul follows the direction of the generated sounds - gently absorbs the audience. S.V. Rachmaninoff, a genius performer himself, wrote, "The very duration of a pause or each note depends on the essence of the soul. The artist's soul dictates how long the pause should be." [8]

What a musician has to do is to listen to and follow his soul and state of mind. "Listening" is the main goal of the performer, the beginning of creativity and its end. The ability to "listen" comes from forbearance, which leads to the understanding that the performer is just an intermediary sharing a certain force. The force itself is distant, thus there is the expectation of the connection with the sublime. This force is called "inspiration" or "revelation", as Beethoven called it. If the performance is only a demonstration of the results of exercising, there will be no place for inspiration on the stage. If there is no inspiration, there will be no miracle.

\footnotetext{
2 Here we emphasize the value of a live performance, the importance of recorded music, however, is not denied.
} 
As stated by V.V. Medushevsky, Professor at the Moscow Conservatory, "Music is a miracle". In fact, there is a profound sound difference between either simply pressing individual piano keys at certain moments, or producing a sound with the expectation of a miracle. In Japanese, the latter is "hajiku" 3 -pressing piano keys with a prayer. The sounds produced by the "click up" method are vibrant, upward and natural, whereas the sounds "pushed down" are dry, dull and artificial. The naturalness of the sound is a special merit of Russian music and the Russian school of music. This naturalness comes from the soul that believes in miracles, as children do. The author of the article has not met any other people, but Russians, living with great faith in miracles. This is the reason for the triumph of arts in Russia.

Many modern people believe that miracles cannot happen. However, according to the great scientist Albert Einstein, "There are only two ways to live your life. One is as though nothing is a miracle. The other is as though everything is a miracle."[9]

The ultimate question is what fills the soul with joy. Engaged in the pursuit of material benefits, people of the modern world often neglect their souls. "For where your treasure is, there will your heart be also" (Gospel of Luke 12:34). When one performs music with the feeling of a miracle, when both music and they find themselves in eternity, when these seconds are about to become a part of this eternity, a unique mastery and the vision of eternity can emanate.

What a performer plays is not notes but music, they touch the world hidden behind the notes. If the performer does not have a religious feeling at that moment, they are left to their own devices: they search for the source of the creative power of music within themselves. Such a performer either is not aware of the presence of the sublime or does not know how to accept it. By and large, a person should turn to the sublime, as without it the performance is soulless and inexpressive.

The expression "higher, longer and further", describing the movements in classical ballet, indicates the further development of arts in general. Classical art, eventually, is destined to integrate with morality, spirituality and religious devoutness. According to R. Schumann, "The laws of morality are also those of Art." [10]; "To send light into the depths of the human heart is the purpose of the artist." [11] This invisible spiritual light is not easy to get; exercise and virtues are required. The performer's playing gives light if they can feel the wind, connect with the wind. In the context of the Bible, wind is the breath of God (Book of

The Japanese word "hajiku" means "hook up", "click up". Its hieroglyphic writing is similar to the word "play": 「弾 $<\rfloor$, they only differ in pronunciation. "Play" is "hiku", while "hook up" is "hajiku".
Genesis 3: 8, Book of Numbers 11:31, Book of Judges $22: 11$, etc.). Performance is synergy (from the Greek

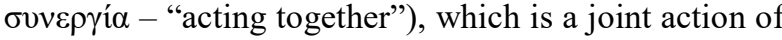
a mortal man and the Almighty.

\section{THE BELIEVING SOUL OF RACHMANINOFF}

What was S.V. Rachmaninoff's vision of the spiritual side of music? In order to investigate this issue fully and correctly, it is essential to touch upon the issue of faith as the basis of the composer's worldview. Until recently, it was believed that the faith supporting Rachmaninoff's spirits was not that strong. The reason for this judgment is rather simple. Firstly, the composer himself was not the person to provide a window onto his personal life. Secondly, in the USSR, in the times of anti-religious propaganda, it was not customary to talk about the religiosity of art workers, scientists, etc. In fact, the question of one's faith is personal and intimate. Reasoning about the power of faith, fundamental to the life of S.V. Rachmaninoff, the genius of world art, who lived in an era of great upheavals and cataclysms, is a difficult subject to study.

Nevertheless, the modern studies on Rachmaninoff present reliable facts about the composer's strong faith. ${ }^{4}$ This is confirmed by the analyses of his works and by historical documents.

Rachmaninoff himself said, "A composer's music should reflect the spirit of the motherland, his love, and his faith." [12] Therefore, the music itself expresses the depth of the composer's soul. In the last years of his life, Rachmaninoff admitted, "Love, bitterness, sadness or religious devoutness - all this is what my music is about." 5 [13] Rachmaninoff particularly valued the spirituality of music. What did the composer consider the source of the creative power of music?

\section{THE SOURCE OF S.V. RACHMANINOFF'S CREATIVE INSPIRATION}

\section{A. The spark of God}

In 1927, to the question of music columnist B. K. Roy about the source of inspiration, 54-year-old Rachmaninoff said, "It is a challenge to think what inspires creativity; so many factors contribute to it. And, of course, love; love is a permanent source of inspiration. It inspires like nothing else. To love means to integrate happiness and the intellective power. It encourages intellectual energy. Natural grandeur and beauty also stimulate creativity. Personally, I am very much inspired by poetry. After music, poetry is my

\footnotetext{
See articles in the Proceedings of the $\mathrm{V}$ Internationa Conference "S.V. Rachmaninoff and world culture" (Ivanovka Museum Estate of S. V. Rachmaninov, 2013): [15];.[16]

From the article in The Etude magazine, published in Philadelphia, December 1941
} 
second favourite. Our Pushkin is outstanding. I constantly read Shakespeare and Byron in Russian translations. I always have poetry at hand. Poetry inspires music, for poetry itself abounds in music. They are twin sisters. Whatever is beautiful helps", said Rachmaninoff and a smile tugged at the corner of his mouth. "A beautiful woman is, of course, a source of eternal inspiration. However, you should run away from her as you see her, otherwise you will be unlikely to compose or complete anything. Get inspired, think of the inspirer, but always be in the privacy of your own mind when engaged in creative work. Real inspiration is found inside. If it is empty inside, nothing from the outside will help. Neither a poetic masterpiece or a great painting, nor the majesty of nature can affect the result, if there is no spark of God in the artist" [14].

Saying "so many factors contribute to it", Rachmaninoff lets us see that it is a great challenge to answer this question briefly. Then he continues with "of course, love". Further he emphasizes it again, "Love is a permanent source of inspiration; "It inspires like nothing else" (he also mentions "poetry" and "whatever is beautiful" as sources of inspiration). Later, however, as if denying the mentioned external sources, he states, "Real inspiration is found inside," and this inspiration is the "spark of God".

For a better and more complete understanding of the "spark of God", let us turn to music as the composer himself defined it.

\section{B. The definition of music}

Five years after the above-mentioned interview, 59eyar-old Rachmaninoff answered the question about his definition of music in the written, poetic form.

What is music!? How can one define it?

Music is a calm moonlit night, a rustling of summer foliage.

Music is the distant peal of bells at eventide!

Music is born only in the heart, and it appeals only to the heart;

It is Love!

The sister of Music is Poesy, and its mother is Sorrow! $[17]^{6}$

6 Rachmaninoff's answer to the question of the definition of music was dated December 13, 1932. The question itself was as follows: "Dear Mr. Rachmaninoff, what is music? When communicating with professional musicians, I frequently addressed the topic of a more philosophical understanding of music, according to which music itself is even more mysterious than the electricity phenomenon. Indeed, I have received so many interesting and even contradictory definitions of music that I began to compile a quote collection with the intention of dedicating it to the interested public: composers, artists, teachers, students, and all those interested in
In this answer, touching upon the source of music Rachmaninoff said, "Its mother is Sorrow!" This definition is unexpected and perplexing. Therefore, we shall carefully consider where the key to understanding this phrase is.

Rachmaninoff"s answer to "What is music!?" has an excellent composition. The meaningfulness of his lines increases gradually and ends with the given definition with "sorrow".

At the beginning, Rachmaninoff uses three artistic images to define music. The first one, "a calm moonlit night", is wonderful; it is absolute silence! A profound idea, which seems to deny the sound itself and describe music as silent darkness illuminated by the moonlight. This reminds of apophaticism. Indeed, numerous musicians admit that music is based on silence. Moreover, our ear will only then be ready to perceive music if it is able to listen to the silence. If playing is such a paradoxical action as filling in silence with sounds, then one could say that it fulfils "eternity with time", "the imperishable with the perishable", "that world with this world", "the immortal with the mortal". This bears strong resemblance with Schelling's idea: "The artwork presents the infinite in finite form".

The second image, "rustling of summer foliage", highlights the serenity of the nature, the quiet timbre is simple but varied. How pleasant and fresh is the rustle of green leaves! It is calm, like purls of water and invisible moves of the wind.

Finally, the image of the "distant peal of bells" is an appeal to the believing soul of a person. This is the image of the church bells ringing for the All-night vigil, which are deeply loved by Rachmaninoff. These sounds turn people to God and remind of eternity after a working day. Like the first image, this one has darker shades. Presumably, the reason is that in order to perceive music one should distract from the momentary and focus on the invisible and eternal, as if they were listening to important words or teachings. "Faith comes by hearing" (Epistle to the Romans 10:17). Actually, music is what educates the ear. Thus, it becomes clear why music relates to the depths of the soul.

The three metaphors mentioned above have one feature in common: they all convey the idea of the

psychology research. I hope you approve of this thought-provoking question. I would be especially grateful to include your answer in my collection, which, I assure you, will be a worthy and important work, presented not only by outstanding musicians, but also by prominent writers, philosophers and well-known philanthropists from among business people and state figures. Will you please give me your definition of music - not just your appreciation of music-making nor your reaction to it, but what music (in the abstract) means to you? As far as I know, no one has ever made such an attempt, and I hope for your kind cooperation for the benefit that this can bring to those creating works and engaged in performing in the field of musical art Sincerely yours, Walter E. Koons" [18,] [Translated from Russian] 
unnoticed silence or a quiet sound. They cover the perception of perspective, the existence of space and humankind, and even a shade of the East. Oddly enough, they emanate the aesthetics characteristic of the Japanese culture - "wabi-sabi" (the Russian culture is definitely closer to the Japanese culture rather than to the Western European one). Not without a reason Kōsaku Yamada noted, "There was something oriental about his [Rachmaninoff's] appearance." [19]

Rachmaninoff continues saying that music is "what is born in the heart and goes to the heart". According to the maestro, music is something that is created in the spiritual world of a person, which appeals to another person with the same spirit. In fact, music cannot be isolated from people; it lives in the heart-to-heart communication. Notes or sounds can exist in isolation but not music. Music can only fully be perceived by one's spirit, which is able to remember its integrity and its changes in time. Having understood this mystery of music filled with life, with no hesitation Rachmaninoff claims, "It is love!" Love is what connects people's hearts.

Further, the maestro mentions the art closest to music-love, "The sister of Music is Poesy". The rhythms, breaths, the sublime world that it praises, the meaning expressed by sound - all of these features inherent in poesy, are inherent in music. Therefore, poesy is rightfully considered the sister of music.

Rachmaninoff culminates his poetic definition with the words on the source of music. He writes, "And its mother is Sorrow!". In other words, Rachmaninoff" music is "love born of sorrow". Love born of sorrow reminds us of Jesus' crucifixion.

Nevertheless, why exactly is "sorrow" the mother of music? In order to solve this conundrum, we consider it important to take the point of sorrow further.

\section{The definition of sorrow}

The word "sorrow" has three meanings. They differ in the distance between the state of joy and the state they denote.

1) Worldly sorrow: In its most common sense, "sorrow" is the opposite of "joy". Typically, this kind of sorrow results from personal problems. Its meaning is close to disappointment and dissatisfaction. This is the most common perception of sorrow; according to it, there is no joy there.

During his lifetime, S.V. Rachmaninoff witnessed the period from the collapse of the Russian Empire to two World Wars. F.M. Dostoevsky characterized this period as the time of "disbelief and doubt". This time was obviously not filled with joy. In reminiscences about the happy time of his life in Russia, Rachmaninoff's separation from his beloved motherland felt more painful. This pain is reflected in Rachmaninoff's compositions.

Up until now, Rachmaninoff's sorrow has been related with worldly reasons (the loss of love or separation from the motherland, etc.); in other words "the sorrow of self-dissatisfaction". Everyone, with no exception of Rachmaninoff, experienced the loss of love or failures. This feeling was expressed in the masterpiece: "Oh no, I pray, don't leave!" op. 4-1. However, is sorrow, which 59-year-old Rachmaninoff called "the mother of music", defined in this way only?

What was he like, having left the motherland? What sorrow did he feel? Forced to follow daily pursuits, he found himself unable to compose anything for ten years. Worldly sorrow results in reduced creative power and desire for life. In the worst case, it leads to suicide. As the Bible says, "Worldly sorrow brings death" (Second Epistle to the Corinthians 7:10).

2) Moral sorrow: Moral sorrow is not personal sorrow, but sorrow to be justified and accepted by society. This sorrow does not produce the same negative reaction in people as the worldly sorrow. On the contrary, a person may sometimes need dramatic sorrow. Not the sorrow of self-dissatisfaction, but the "sorrow of fulfilling one's duty". Here social ideals are superior to the personal ones. As can be seen from his numerous high-spirited compositions, this kind of sorrow was not strange to S.V. Rachmaninov.

Here distant joy appears along with sorrow. The fulfilment of a duty always brings joy; and the further it goes, the more sorrow and joy integrate. As a result, a state is formed that can be described by Schubert's words: "When I wished to sing of love, it turned to sorrow. And when I wished to sing of sorrow, it was transformed for me into love." Anywhere and anytime, the birth of a person or the creation of a work of art are accompanied by both anguish and joy.

3) Godly sorrow (sorrow to the glory of God): This sorrow contrasts with "self-complacency"; its meaning is opposed to that of the worldly sorrow, which is egocantered. The core of the godly sorrow in its turn is God. It is connected neither with self-dissatisfaction, nor with the sorrow of fulfilling one's duty. It is the sorrow of self-awareness: no matter how well one performs their duties, they never reach perfection (see Gospel of Luke 17:10). It is the sadness of repentance, true sorrow, and sorrow because of faith. This sorrow can be called Christian sorrow; it is often mentioned in the Bible: "We wait in hope for the Lord; he is our help and our shield" (Psalm 33:20); "For it has been granted to you on behalf of Christ not only to believe in him, but also to suffer for him" (Epistle to the Philippians $1: 29)$; "In this world you will have trouble" (Gospel of 
John 16:33), etc. This sorrow leads to genuine repentance and makes us realize "our frailty". 7

In his later years, being under severe stress and suffering from serious illnesses, Rachmaninoff said with self-reproach, "In my lifetime I did not manage to do everything I could." [20] This, however, was said when he took on the task of creating the Symphony No. 3 , and 59 concerts were scheduled for the season in the cities around Europe and America [21]. Such severity towards himself reflects his "godly sorrow" brought by the vision of the high artistic ideal.

Saints are known to see their sins more clearly than ordinary people do. The Church Fathers associate the purity of the soul with the cleanliness of the clothing and say that the cleaner the clothing, the more distinctive any dirt is. Thus, the purer the soul, the more clearly it sees sins. Paul the Apostle called this sorrow, born of conviction "godly sorrow" and contrasted it to the worldly sorrow: "Godly sorrow brings repentance that leads to salvation and leaves no regret, but worldly sorrow brings death" (Second Epistle to the Corinthians 7: 10).

This sorrow is not distant from joy; on the contrary, it implies taking spiritual joy.

\section{Substantiation of the analysis method}

The analysis above is based on a parable that the author of the present article heard from Professor V.V. Medushevsky, while studying. This parable produced a lasting impression on the author and had a significant impact on his creative activity. We would like to recite it to justify the applied method of analysis. This parable is as follows:

Three men were working and moving large stones from one place to another. A passer-by asked the workers what they were doing and they all gave different answers. The first man answered uninterestedly: "I am earning my daily bread". The second man answered, mopping his perspiring face: "I am doing this to provide for my family!" Finally, the third man answered exuberantly: "I am building the

This type of sorrow was and still is the subject for discussion. Elder Nikolay (Guryanov) $(1909-\uparrow 2002)$ : "My soul is killed by sorrow / I fail to obey Your will / The door to salvation is closed for me / The road to the Creator is closed for me / Closed by my own passions / They have grown for years / Too many of them have grown". St. Isaac the Syrian: "When one observes fasts, prayer emanates from their heart, their face expresses sorrow, evil thoughts are away, lusts and vain discourse are alien to them" [22]. M. Lermontov: "At times of grief and sorrow/ When life hits really hard/ One magic, charming prayer/ My lips repeat by heart..." The instruction that St. Silouan the Athonite $(1866-\dagger 1938)$ received from the Lord is should be mentioned: "Keep your mind in Hell and despair not" (Emphasis added).

8 Letter to Wilschau, dated October 26, 1935. Three years after writing the "Definition of Music". Rachmaninoff was often selfreproaching, but it greatly intensified in his later years. temple of God!" The message in this parable conveys is that all three men were doing the same job, but their goals and state of mind were entirely different.

This parable should be interpreted in accordance with the teachings of the Orthodox Church, in which the human being is threefold (body, soul and spirit). The images of the men illustrate different goals and states of mind. The state of mind in its turn alters the view of life and the purpose of work. Figuratively speaking, the world can become either heaven or hell, depending on the state of mind.

It should be noted that in the context of the New Testament the "temple of God" means both the living temple of God (body) and life itself (Second Epistle to the Corinthians 6:16, etc.). This is the reason why the words of the parable "building a temple" mean not only constructing a material temple or performing a practical task, but also "building life according to the will of God" (Epistle to the Ephesians 2: 19-22). This parable communicates a deep meaning of allegiance. In the Orthodox tradition, the expressions "to build the temple of God", "to build a house", are used metaphorically, mean "to build the Temple of one's soul" and imply the education of one's soul by repentance and virtue.

Thus, there are three meanings in sorrow. Each of them is represent in Rachmaninoff's music. Meanwhile, is it correct to consider the sorrow, which the composer called the "mother" of music "godly sorrow"?

\section{GODLY SORROW OF S.V. RACHMANINOFF}

Firstly, let us turn to Rachmaninoff's words about the "source of music". In the essay "Living Spark" from in the last chapter of "Ten essentials of artistic piano playing" (first published in March 1910, in The Etude magazine), discussing performance, the 36-year-old Rachmaninoff mentions joy brought by inspiration.

"In every quality piano performance there is a very important spark that seems to turn any interpretation into a living work of art. It only exists at some moment and cannot be explained. For instance, let us take two pianists possessing the equal technical skills and playing the same composition. The performance of one of them is dull, lifeless, and learned by heart, while the other presents something out of the ordinary. It is full of life; it engages and inspires the audience. What is this important spark that breathes life into notes? "[23].

He calls this spark "inspiration" and highlights, "When creating music, a composer is inspired; so if the performer experiences the same joy, which the author felt at the moment of creation, their performance becomes more impressive, vibrant and gains strength." [24]

Thus, if "joy" brings inspiration, "worldly sorrow" cannot be the source of this joy: more likely, it is 
"godly sorrow". Then, the maestro writes that "if the performance itself" becomes "filled with inspiration", even some "technical inaccuracy" is forgiven. Rachmaninoff finishes his "Living spark" with the following words: "In essence, this vitally important living spark is the soul in itself; it is the source of the highest expression in music" [25].

Rachmaninoff claimed that this vitally important living spark is the soul in itself and it is exactly the soul, which "is the source of the highest expression in music". It is the soul, which has been nurtured by the Russian Orthodox culture and is filled with the Russian spirit in all spheres of life, not arts exclusively; the soul, which has uncovered the "secret of exercise (asceticism) and inspiration".

"But seek first God's Kingdom, and his righteousness" (Gospel of Matthew 6:33), so taught the Lord; and "the Kingdom of God is within you" (Gospel of Luke 17:21). St. Isaac the Syrian explained these lines in the following way. "Enter your inner room, and there you will see the room of Heaven. They are the one, so entering one of them you see both. The ladder to this Kingdom is inside you. Repent of your sins, and you will be able to ascend" [26].

As Rachmaninoff said, "the vitally important living spark is the soul in itself" and "real inspiration is found inside" [27], so we can assume he had awareness of his "inner room" and gained a living spark there. The "inner room" is a secret place in the depths of one's soul, that is, the spirit. The "sorrow", which Rachmaninoff called the mother of music, should be understood within this semantic range.

It can be noticed in any Rachmaninoff's composition that his sorrow does not evoke the feeling of despair. On the contrary, it produces the healing effect on the audience, leaves them with the feeling of serenity, and enables the listeners to receive the energy of another dimension, filled with joy and courage. Thus, Rachmaninoff's "sorrow" is a state of mind to find inspiration. The composer asserts that remarkable performance requires deep thinking [28,], and music should reveal deep feelings [29,], which means that the concept of sorrow in the definition "its mother is Sorrow" conveys a deeper meaning than that of "worldly sorrow" or "moral sorrow".

Godly sorrow, that is, sorrow to the glory of God, to the construction of the temple of God, to bringing virtues $^{9}$. S.V. Rachmaninoff was a true virtuoso of the 20th century. No wonder that the word "virtuoso" is derived from the word "virtue". As the Professor of the

On the importance of virtues: "join moreover virtue with your faith: and with virtue, knowledge. And with knowledge, temperance: and with temperance, patience: and with patience, godliness: And with godliness, brotherly kindness: and with brotherly kindness, love" (The Second Epistle General of Peter 1:5).
Moscow Conservatory P.T. Nersessian emphasized, "First, overcoming difficulties, and then gaining victory." The development of the given talent lies in hard work and sorrow, only then one's mastery can be recognized as a "virtue" (Gospel of Matthew 25: 1420). It is remarkable that S.V. Rachmaninoff, "the most successful of the emigrant musicians from Russia" [30], donated a substantial sum of money earned by his mastery to support his suffering compatriots, and did it secretly, avoiding publicity.

There exist visible (external) and invisible (internal) virtues. External virtues are associated with the danger of vanity, while the internal ones reduce it. According to B. Nikitin, in Rachmaninoff's family, the warning expression "le péché d'orgueil" (the sin of pride) was frequently used in communication [31], which illustrates their focus on inner virtues. Evidently, having a God-given talent and excellent education and even being at the peak of his creative career, Rachmaninoff devoted assiduous attention to inner virtues.

Thus, it is a fair assumption that the sorrow, which Rachmaninoff called the mother of music, is not passive and its meaning is beyond "worldly sorrow". It is the state of the expectation of "inspiration bringing creative joy" and "godly sorrow" to accompany asceticism and virtues. This relationship was well explained by St. Isaac the Syrian, "If you desire virtue, than give yourself to every affliction, for afflictions produce humility." $[32]^{10}$

This appears to be the most convincing explanation of the "sorrow" Rachmaninoff was writing about. In fact, both Rachmaninoff's life and music were accompanied by sorrow at desiring for virtue; and therefore, as he gave himself to afflictions, which led to humility, divine grace (music) was given to him. ${ }^{11}$

\section{CONCLUSION}

The source of the creative power of music is a mystery. "When performing creative work", one should "always be in the privacy of one's own mind", as asceticism filters the unnecessary and focuses the spirit. The godly sorrow born of asceticism and virtue prepares a place for inspiration. As the sun's heat is concentrated with a magnifying glass, which soon sparks the fire, a "living spark" arises in the prepared,

10 "It is impossible to draw near to God without sorrows, without which human righteousness cannot remain unchanged... If you desire virtue, than give yourself to every affliction, for afflictions produce humility. If someone abides in virtue without afflictions, the door of pride is opened to him" [35,]

11 "Grieve, mourn and wail. Change your laughter to mourning and your joy to gloom. Humble yourselves before the Lord, and he will lift you up" (Epistle of James 4:9-10); "Very truly I tell you, you will weep and mourn while the world rejoices. You will grieve, but your grief will turn to joy" (Epistle of John 16:20), etc. 
concentrated soul. This inspiration brings creative joy to composers and performers. Of course, in reality, not everything works according to fixed patterns. After all, "the wind blows wherever it pleases; you hear its sound, but you cannot tell where it comes from or where it is going" (John 3: 8). Thus, we should be guided by the Japanese saying「人事を尽くして天命を待 て」("Man proposes, but God disposes"). That was the reason for Rachmaninoff to highlight, "It [a spark] only exists at some moment and cannot be explained".

Following Rachmaninoff, music is love that is born in the heart and goes to the heart. This love (music) is associated with Love on the Cross, because it will be born in sorrow; and also with the Source of life (the Creator). Rachmaninov called the source of creative power "the inspiration of love" or the "spark of God". He placed considerable emphasis on the following: "If it is empty inside, nothing from the outside will help. Neither a poetic masterpiece or a great painting, nor the majesty of nature can affect the result, if there is no spark of God in the artist." [33]

Rachmaninoff listened to his inner voice and as he expressed it, tried to simply pour out his heart [34]. Either in sorrow or with a prayer to God, he realized that God is the source of music. He mentioned, "I owe my talent to God, to Him alone. Without him, I am nothing." 12 .The genius expressed "his misery without God" and "gratefulness to God".

It should be mentioned that Rachmaninoff's "godly sorrow" grew deeper with years. In his letter written two years before his death (when he was about 68 years old), the maestro revealed his extreme spiritual condition: "I am tired! Exhausted! I cannot remember if I ever felt that tired <...> Though, I should say, thanking God with all my soul, during the concerts I feel much better" (a letter to S. A. Satina, dated January 27, 1941) [36,]. Thus, through these words we see a humble artist, acknowledging his weakness, who goes on stage with a prayer to God and puts all possible efforts in fulfilling his life mission. Otherwise, he would not have wholeheartedly thanked God for the power that supported him at concerts.

The author of the article produced the described ideas and reached the above stated conclusions when rehearsing certain compositions and further performing them on stage. This work implied not only learning the scores, studying the history of the creation of each work, its musical analysis and listening to the recordings of the composer himself. It also involved substantial inner work - listening intently to the voice of the composer's heart, concentrating on every minor detail (internal search for performing ideas), getting

12 From the interview in Brussels, 1933. The Definition of Music was written a year before closer to the essence of each work through movement, as well as working on the spiritual side - praying. Thorough work and prayer for the gift of inspiration on stage reveal the law of creative power.

As Rachmaninov once stated, "In fact, no one is able to express in written media everything that a teacher can pass along in live communication." [37] It is a challenge to formulate this law in words; however, we hope that the ideas and conclusions of the present article may work as the guidelines for musicians on performing music.

What does the performer rely on when going on stage? What is the purpose of his playing? What should the movement of his soul correspond with?

Judging by the author's personal experience, when the soul is filled with sorrow rather than joy, the performance is usually more vibrant. In the state of sorrow, the performer experiences a feeling directly penetrating into their soul (in Japanese, the author applies the expression す $っ と$, which means "freely, gently, fast", the words derived from it are $す っ と す$ る - to feel relief, and すっと立ち上がる - to liven up). In this inner simplicity, when nothing interferes with the sound communication of both sides, the melody, singing, and music appear by themselves. The performer themselves is taken aback by what is happening. Such a condition is often seen after fatigue or creative blocks. Grace descends from Heaven to those in misery, which can be called the law of the Holy Spirit. Of course, this is a purely spiritual aspect, where much depends on the personality of the performer, but according to the author's experience, if one strives for sorrow (repentance), they receive the good as a result: "blessed are those who mourn" (Gospel of Matthew 5: $4)$.

"Music is love!" And if "music is love", then performing music is the energy ascribing glory to love. One does not have to play or express anything; what they should do is to give everything to God and fill the heart with love and tears, as "filling" is the target point of the performance.

\section{References}

[1] S. Rachmaninoff: literary heritage. 3 vols. Ed. and comp.by Apetian Z. A. M.: Sovetskii Kompozitor, vol. 3, p. 2381978.

[2] Research on Seiji Ozawa. ARC publishing. Tokyo: Shunjusha, 1990.

[3] Venerable Barsanuphius of Optina. Talks. Cell notes. Spiritual poems. Memories. Letters. Wreath for the Father's grave. p. 356 Vvedensky stauropegion monastery Optina Pustyn, 2009. In Russian

[4] S. Rachmaninoff: literary heritage. 3 vols. Ed. and comp.by Apetian Z. A. M.: Sovetskii Kompozitor, vol. 1, p. 95, 1978

[5] Ibid vol. 1, p. 52 
[6] Ibid vol. 1, p. 52

[7] The Complete Works of Kōsaku Yamada. Vol. 2. Tokyo: Iwanami Shoten Publishing, 2001..( P.9)

[8] S. Rachmaninoff: literary heritage. 3 vols. Ed. and comp.by Apetian Z. A. M.: Sovetskii Kompozitor, vol. 3, p. 2401978.

[9] Words of Einstein. Translated by Takashi Yuba. Tokyo: Discover 21 Publishing, 2015.

[10] R. Schumann, Music and Musicians. Tokyo: Iwanami Bunko, 2011. P239.

[11] Ibid, p219

[12] S. Rachmaninoff: literary heritage. 3 vols. Ed. and comp.by Apetian Z. A. M.: Sovetskii Kompozitor, vol. 1, p. 145-147, 1978.

[13] Ibid

[14] Ibid, vol. 1, pp. 94-95

[15] Aleinikov M. I. On religion in the spiritual world of S.V. Rachmaninoff (details to the composer's portrait). The Proceedings of the V International Conference "S.V. Rachmaninoff and world culture" p.18-23, (Ivanovka Museum Estate of S. V. Rachmaninov), 2013. In Russian

[16] Zvereva S. G. On Rachmaninoff's musical concepts in the mid1930s. The Proceedings of the V International Conference "S.V. Rachmaninoff and world culture" P. 35 (Ivanovka Museum Estate of S. V. Rachmaninov), 2013.

[17] S. Rachmaninoff: literary heritage. 3 vols. Ed. and comp.by Apetian Z. A. M.: Sovetskii Kompozitor, vol. 2, p.343, 1978.

[18] Ibid, vol. 2, pp. 550-551

[19] The Complete Works of Kōsaku Yamada. Vol. 2. Tokyo: Iwanami Shoten Publishing, 2001..( P.9)

[20] Rachmaninoff: literary heritage. 3 vols. Ed. and comp.by Apetian Z. A. M.: Sovetskii Kompozitor, , vol. 3, p. 611978

[21] Fumiko Hitotsuyanagi. Revealing the true image of Rachmaninoff. Tokyo: Toyo Shoten Publishing, 2012. (p. 57)

[22] Isaac the Syrian. Ascetic words. p. 142, M. Pravilo Very, 2002

[23] S. Rachmaninoff: literary heritage. 3 vols. Ed. and comp.by Apetian Z. A. M.: Sovetskii Kompozitor, vol. 3, p. 239-240, 1978.

[24] Ibid

[25] Ibid

[26] Isaac the Syrian. Ascetic words. p. 16, M. Pravilo Very, 2002

[27] S. Rachmaninoff: literary heritage. 3 vols. Ed. and comp.by Apetian Z. A. M.: Sovetskii Kompozitor, vol. 1, p. 95, 1978.

[28] Ibid, vol. 3, p. 240

[29] Ibid, vol. 1, p. 114

[30] Fumiko Hitotsuyanagi. Revealing the true image of Rachmaninoff. Tokyo: Toyo Shoten Publishing, 2012. (p. 54)

[31] Nikitin B.S. Sergei Rachmaninoff: Two Lives. P. 22, M.: Klassika-XXI, 2009.

[32] Isaac the Syrian. Ascetic words. p. 236, M. Pravilo Very, 2002

[33] S. Rachmaninoff: literary heritage. 3 vols. Ed. and comp.by Apetian Z. A. M.: Sovetskii Kompozitor, vol. 1, p. 95, 1978

[34] Ibid, Vol.1, p, 147

[35] Isaac the Syrian. Ascetic words. p. 236, M. Pravilo Very, 2002

[36] S. Rachmaninoff: literary heritage. 3 vols. Ed. and comp.by Apetian Z. A. M.: Sovetskii Kompozitor, vol. 3, p. 188, 1978

[37] Ibid, vol. 1, p. 232 